\title{
GAME ONLINE DAN PENGARUHNYA TERHADAP KOMUNIKASI DALAM KELUARGA (STUDI KASUS TAMBAKBAYAN YOGYAKARTA)
}

\author{
Aloysius Bagas Pradipta Irianto' ${ }^{1}$, Aninda Milenia Putri Wisnu'), Dhea Indriani Putri Aprilli ${ }^{3)}$, Hary Rizki \\ Hermawan ${ }^{4}$, dan Vincent Immanuel ${ }^{5}$ \\ 1,2,3,4,5Program Studi Sistem Informasi, Fakultas Teknologi Industri,Universitas Atma Jaya Yogyakarta \\ 1,2,3,4,5 Jl. Babarsari 43 Yogyakarta 55281

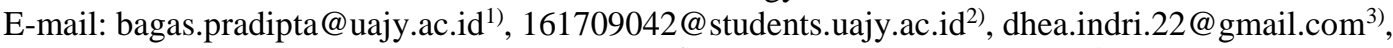 \\ anonymous03r@gmail.com ${ }^{4)}$, vincent29nuel@gmail.com ${ }^{5)}$
}

\begin{abstract}
ABSTRAK
Game Online merupakan sarana yang digunakan oleh banyak orang untuk menjalin suatu komunitas atau hanya sekedar untuk hiburan semata, dalam hal ini tentu orang tua juga mempunyai peran dalam memberi pengarahan untuk membatasi waktu anak agar tidak kecanduan saat bermain game online. Penelitian ini mengungkap pengaruh game online terhadap komunikasi antara anak dan orang tua di dalam lingkup keluarga. Didapatkan fakta bahwa 52,8\% anak lebih sering bermain game lebih lama dibandingkan berkumpul dan bermain bersama anggota keluarga. Fakta lain yang didapat adalah 58,5\% anak lebih sering menyendiri saat bermain game dibanding berinteraksi dengan lingkungan sekitarnya. Orang tua juga memiliki peran, $54,7 \%$ responden membatasi waktu (jam) bermain game anak sehingga komunikasi tidak terganggu. $58,5 \%$ orang tua menyatakan komunikasi anak tidak terganggu.
\end{abstract}

Kata Kunci: Pengaruh komunikasi, Game Online, Komunikasi, Komunikasi keluarga, Peran orang tua.

\section{PENDAHULUAN}

Kemajuan ilmu pengetahuan dan teknologi (IPTEK) adalah suatu hal yang sangat menguntungkan berbagai pihak di seluruh aspek lapisan masyarakat. Kemajuan IPTEK memiliki tujuan utama yaitu mempermudah manusia dalam melakukan pekerjaannya, keefektifan dan keefisienan waktu (Liantoni $d k k$., 2018). Secara umum, teknologi didefinisikan sebagai sebuah proses yang mentransformasikan bahan baku mentah atau modal intelektual menjadi sebuah produk ataupun jasa (Liantoni dkk, 2018).

Teknologi informasi merupakan kunci perkembangan bagi manusia dan organisasi (Irianto, 2018). Namun demikian perkembangan teknologi yang pesat menyebabkan penguasaan teknologi pada masyarakat berkurang (Mustaffa dan Ibrahim, 2014). Namun demikian perkembangan teknologi memiliki kelemahan antara lain: semakin berkembangnya cyber crime (kejahatan menggunakan teknologi), mulai minimnya interaksi antar masyarakat dan bahkan keluarga, berkembangnya informasi secara bebas tanpa disaring terlebih dahulu, dan berkembangnya berita bohong (hoax) (Amarini, 2018). Tidak dapat dipungkiri bahwa teknologi internet dapat memberikan kemudahan bagi siapa saja yang menggunakanya termasuk anak-anak dan remaja. Namun internet tanpa kontrol dapat menimbulkan gangguan seperti kecanduan pada penggunanya (Nahar $d k k ., 2018$ ).

Game online dapat mengganti keberadaan permainan - permainan tradisional. Namun hal tersebut dapat menjadi penghubung antara permainan tradisional dengan game online saat ini (Fajrin, 2015). Dengan adanya hal tersebut, tentu waktu anak-anak akan semakin banyak tersita karena daya tarik yang ditawarkan oleh game online tersebut.

Salah satu penyimpangan sosial yang dilakukan anakanak, dan anak usia remaja saat ini akibat kecanduan game online antara lain masalah perilaku komunikasi antar personal (Aziz, 2016). Game online juga dapat menyebabkan kepribadian ganda. Dimana seseorang yang sering memainkan game online setiap hari selama tiga bulan dengan beberapa tokoh/karakter berbeda menyebabkan tokoh/karakter imajinasi dalam permainan mempengaruhi perilaku dan keputusan orang tersebut (Schimmenti $d k k ., 2017)$. Di dalam penelitian yang lain menyebutkan bahwa keterbukaan akan sesuatu hal berhubungan positif dengan penemuan dan motivasi bermain, sedangkan kesadaran berhubungan positif dengan motivasi pelarian pada realitas (Paisol Burlian, 2016).

Penelitian ini bermanfaat bagi masyarakat sebagai dasar pengambilan sikap orangtua pada anak-anak yang gemar dan sering bermain game online. Penelitian ini juga ingin mengungkap pola komunikasi pada anak yang gemar bermain game online dengan keluarga.

\section{RUANG LINGKUP}

Penelitian ini terbatas pada masalah komunikasi yang muncul antara anak dengan orang tua sebagai akibat penggunaan game online. Penelitian ini ingin melihat bagaimana orangtua menyikapi anak-anak mereka yang gemar bermain game online. Selain itu penelitian ini juga akan mengungkap ada tidaknya perubahan sikap anak setelah mereka bermain game online. 
Hasil dari penelitian akan mengungkap bagaimana pola komunikasi antara anak dengan orang tua di tengah perkembangan teknologi khususnya game online.

\section{BAHAN DAN METODE}

Bahan dan metode penelitian ini digambarkan dalam gambar 1 berikut ini.

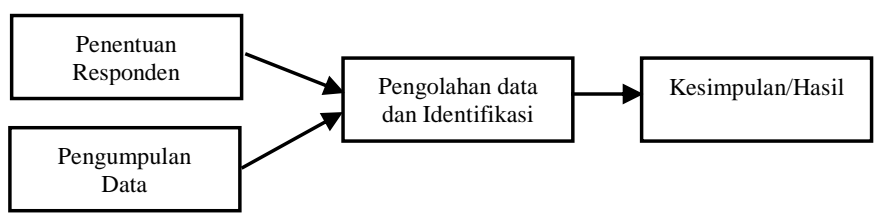

\section{Gambar 1. Alur penelitian}

1. Penentuan responden

Responden yang akan digunakan dalam penelitian ini adalah orang tua yang sudah memiliki anak dan masih tinggal bersama, serta anak yang gemar menghabiskan waktu untuk memainkan game online. Responden diambil keluarga yang tinggl didaerah Tambakbayan, Yogyakarta.

2. Pengumpulan data

Setelah responden ditentukan langkah selanjutnya adalah pengumpulan data. Data dikumpulkan dengan menggunakan kuesioner dan interview secara langsung. Dari hasil pengumpulan data didapatkan data responden sejumlah 53 responden

3. Pengolahan data dan identifikasi

Data yang didapatkan pada langkah 3.2 kemudian diolah dengan menggunakan langkah-langkah sebagai berikut :

1) Mengorganisasikan data yang sudah kita kumpulkan dari pihak terkait.

2) Mengidentifikasi dampak yang ditimbulkan game online terhadap relasi anak dan orang tua, baik itu positif dan negatif.

3) Mencari refrensi pendukung dari jurnal ataupun makalah resmi terkait yang mampu mendukung dasar teori kita.

4) Terakhir mendokumentasikan hasil penelitian sehingga menjadi dokumen penelitian yang bisa dipertanggungjawabkan.

4. Hasil

Dari tahap pengolahan data dan identifikasi kemudian disimpulkan mengenai dampak yang ditimbulkan game online dalam komunikasi didalam keluarga.

\section{PEMBAHASAN}

Bagian ini merupakan penerapan dari kerangka penelitian pada bagian sebelumnya.

\subsection{Data Responden}

Dari seluruh kuesioner yang disebar dan hasil wawancara secara acak, didapatkan 53 sampel responden yang lengkap dan layak untuk digunakan sebagai data penelitian. Dari 53 responden tersebut dibagi menjadi 2 bagian yaitu data responden anak dan data responden orangtua, dapat dilihat pada tabel 2 dan 3 .

Tabel 2. Data Responden Orang Tua

\begin{tabular}{ccc}
\hline Kategori & Jumlah & Prosentase \\
\hline Jenis Kelamin: & & \\
Laki-laki & 23 & 43,00 \\
Perempuan & 30 & 57,00 \\
Usia: & & \\
$21-25$ th & 2 & 4,00 \\
$26-30$ th & 1 & 2,00 \\
$31-35$ th & 16 & 30,00 \\
$36-40$ th & 14 & 26,00 \\
$41-45$ th & 9 & 17,00 \\
$46-50$ th & 8 & 15,00 \\
$51-55$ th & 3 & 6,00 \\
\hline
\end{tabular}

Tabel 3. Data Responden Anak

\begin{tabular}{ccc}
\hline Kategori & Jumlah & Prosentase \\
\hline Jenis Kelamin: & & \\
Laki-laki & 42 & 79,00 \\
Perempuan & 11 & 21,00 \\
Usia: & & \\
$1-5$ th & 1 & 2,00 \\
$6-10$ th & 18 & 23400 \\
$11-15$ th & 27 & 51,00 \\
$16-20$ th & 7 & 13,00 \\
\hline
\end{tabular}

Tabel 2 menunjukan jumlah ibu lebih banyak dari pada jumlah bapak yang menjadi responden penelitian ini, $57 \%$ perempuan/ibu dan $43 \%$ laki-laki/bapak. Sedangkan pada tabel 3 tampak laki-laki mendominasi responden dengan $79 \%$ responden, dan perempuan $21 \%$.

\subsection{Analisis Hasil}

Dari hasil kuesioner pada pertanyaan pertama didapatkan fakta bahwa anak-anak yang suka bermain game lebih banyak dari anak yang tidak suka bermain game.

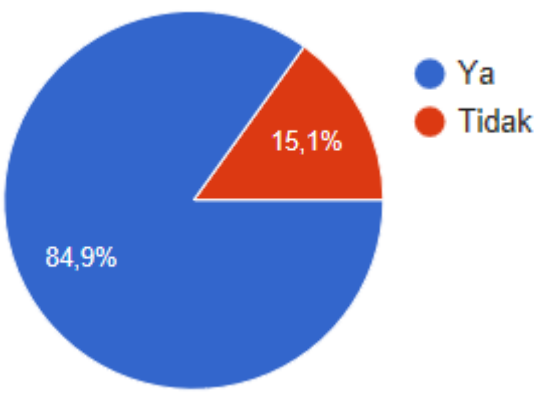

Gambar 2. Anak Senang Bermain Game 
Pada gambar 2 dapat dilihat sebanyak 84,9\% senang bermain game online dan $15,1 \%$ tidak senang bermain game online. Orang tua cenderung memberikan gadget untuk bermain game karena dirasa praktis untuk menenangkan anak yang sedang jenuh. Di sisi lain, beragam aplikasi game yang menarik dapat di unduh melalui gadget.

Hal tersebut juga terbukti karena saat ini banyak terdapat game online yang mengusung tema 90an. Sehingga anak tertarik untuk bermain game pada gadget yang menurutnya lebih praktis dan lebih menarik. Karena game biasanya memiliki tingkat atau level kesulitan tertentu yang membuat anak merasa tertantang dan tidak mudah bosan.

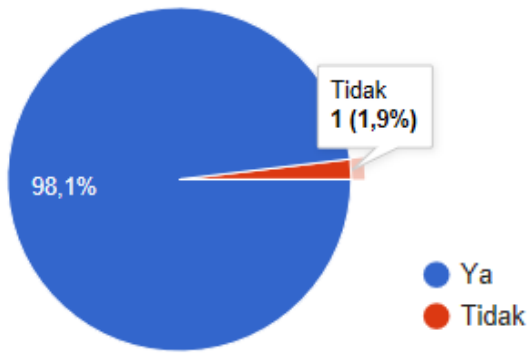

Gambar 3. Pandangan orang tua terhadap anak saat bermain Game

Dari hasil kuesioner pada pertanyaan kedua didapatkan fakta bahwa lebih banyak orang tua melihat anaknya terlihat senang ketika bermain game daripada yang terlihat biasa saja atau tidak senang. Pada Gambar 3 dapat dilihat sebanyak $98,1 \%$ menurut orang tua, anakanak mereka terlihat senang ketika bermain game dan menikmati game tersebut dan sebanyak 1,9\% mengatakan bahwa anak mereka terlihat biasa saja atau bahkan tidak senang saat bermain game. Pada sebuah penelitian dibuktikan bahwa game memiliki potensi untuk menarik anak-anak menjadi lebih aktif dan memiliki nilai lebih kepada anak yang menghindari permainan tradisional. Dibandingkan dengan menonton televisi, anak lebih terlihat senang saat bermain game karena dengan bermain game, dapat memacu kerja jantung menjadi semakin meningkat yang menghasilkan semangat anak, maka anak menjadi senang dan tidak mudah bosan.

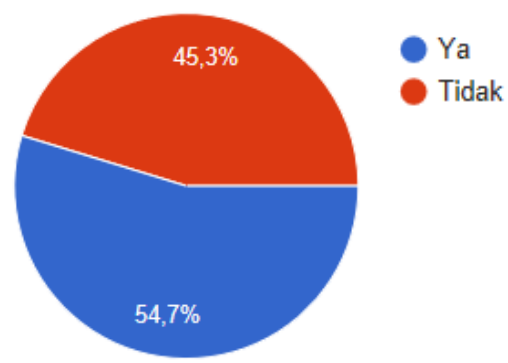

Gambar 4. Anak Memiliki Banyak Teman Karena Bermain Game
Selanjutnya dari hasil kuesioner pada pertanyaan ketiga didapatkan fakta bahwa anak memiliki banyak teman ketika ia sedang bermain game. Pada Gambar 4 dapat dilihat sebanyak $54,7 \%$ menurut orang tua, anakanak mereka memiliki banyak teman karena game dan sebanyak 45,3\% mengatakan bahwa game tidak mempengaruhi banyak atau tidaknya teman yang dimiliki anak. Remaja dan anak-anak merupakan target utama atau pemirsa untuk iklan-iklan game yang ada dan menimbulkan peningkatan kecanduan game (Rikky dan Jusuf, 2017). Di dalam game biasanya pengguna dapat masuk ke dalam grup, kelompok, virtual fantasy world. Bagian terpenting dalam game ialah membuat hubungan sosial namun dalam bentuk nyata. Oleh karena itu, pengguna lebih banyak menemukan teman di dalam game dibandingkan di dunia nyata.

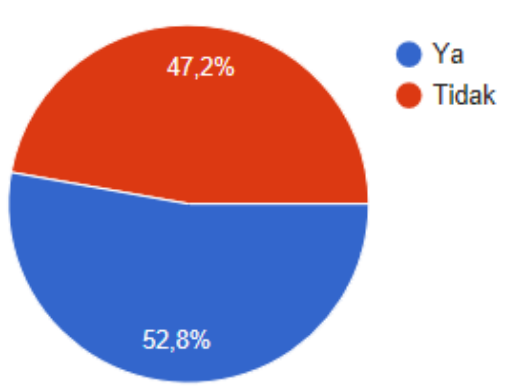

\section{Gambar 5. Anak Menghabiskan Waktu Bermain Lebih Banyak}

Didapatkan fakta $52,8 \%$ anak lebih sering bermain game lebih lama dibandingkan berkumpul dan bermain bersama anggota keluarga. Sisanya 47,2\% menyatakan bahwa anak lebih banyak menghabiskan waktu dengan keluarga dibandingkan dengan bermain game. Pada gambar 5 terungkap fakta bahwa anak cenderung lebih suka bermain game daripada harus berkumpul bersama anggota keluarga. Hal ini dikarenakan anak lebih banyak menggunakan waktu luang nya untuk bermain game. Jika anak merasa bosan, hal yang di tuju ialah bermain game. Rikky dan Jusuf juga setuju bahwa game online sangat amat menyita waktu, padahal masih banyak hal lain yang dapat dilakukan selain bermain game (Rikky dan Jusuf , 2017).

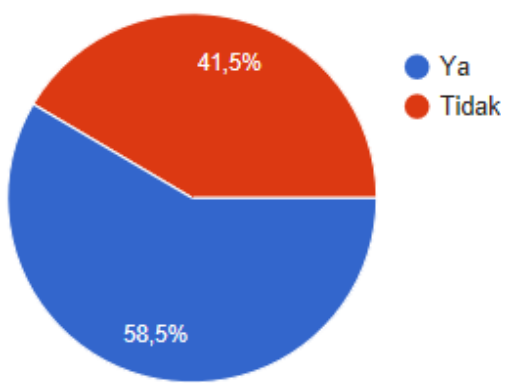

Gambar 6. Anak Menyendiri Ketika Bermain Game. 
Dari 52,8\% anak menghabiskan waktu bermain game lebih banyak dibanding berkumpul dengan keluarga didapatkan fakta $58,5 \%$ anak memang lebih sering menyendiri saat bermain game dibanding berinteraksi dengan lingkungan sekitarnya. Sisanya $41,5 \%$ tidak suka menyendiri ketika bermain game. Dari hasil (gambar 6) didapatkan fakta bahwa anak cenderung lebih suka menyendiri ketika bermain game. Terdapat satu penelitian yang setuju dengan hasil kuesioner gambar 6. Pada penelitian tersebut mengatakan aplikasi permainan yang terdapat pada gadget anak-anak lebih menarik perhatian anak-anak dibandingkan dengan permainan - permainan yang terdapat di lingkungan sekitarnya. Selain itu juga, orang tua mengiyakan bahwa saat anak-anaknya bermain gadget cenderung anak-anak ini diam di depan gadgetnya masing-masing tanpa mempedulikan dunia sekitarnya (Novitasari dan Khotimah, 2016).

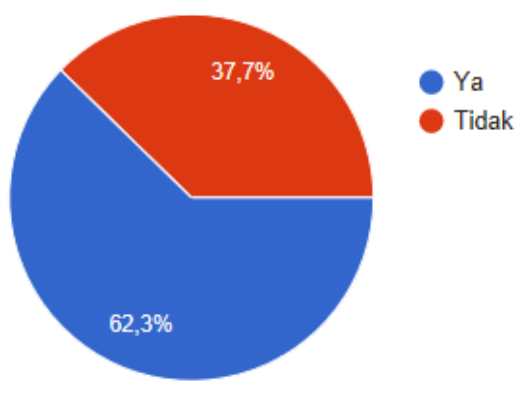

\section{Gambar 7. Anak Merasa Marah atau Kecewa}

Pada penelitian ini juga dicari tahu apakah anak akan merasa marah atau kecewa jika tidak dapat bermain game atau memegang gadget dalam sehari. Hasilnya $62,3 \%$ orang tua mengatakan anaknya merasa marah atau kecewa dan 37,7\% mengatakan tidak marah atau kecewa (gambar 7). Hal ini sesuai dengan yang disampaikan Ridwan bahwa faktor yang menjadi penyebab kecanduan bermain game sehingga anak tidak bisa lepas dari game ialah dengan tersedianya fasilitas bermain game di rumah, pengaruh lingkungan sekitar, adanya keingintahuan tentang jenis game dan keinginan yang besar untuk memainkannya (Syahran, 2015).

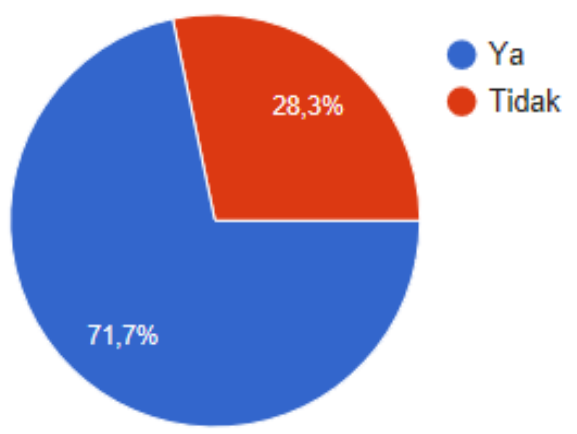

Gambar 8. Anak Sangat Fokus Bermain Game
$71,7 \%$ orang tua mengatakan bahwa anak sangat fokus ketika bermain game dan tidak menghiraukan sekitarnya, dan 28,3\% lainnya merasa bahwa ketika anak bermain game, fokusnya tidak ter alihkan hanya ke game saja, melainkan anak masih peka dengan lingkungan sekitarnya (gambar 8). Ridwan juga menegaskan bahwa anak memang menjadi susah untuk disuruh oleh orang tua ketika asyik bermain game dan menjadi lupa waktu. Hal tersebut menyebabkan anak menjadi kurang peka dengan lingkungan sekitarnya bahkan di dalam lingkungan keluarga (Syahran, 2015).

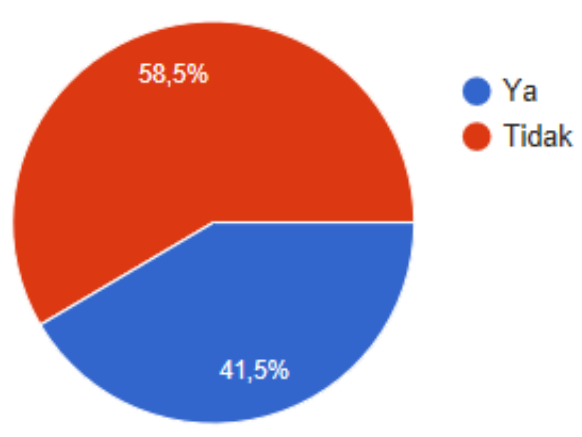

\section{Gambar 9. Komunikasi Anak dan Orang tua Menjadi Jarang}

Walaupun $71,7 \%$ menyatakan bahwa anak sangat fokus ketika bermain game, hal tersebut tidak mempengaruhi komunikasi antar anak dan orang tua. Dengan kata lain, komunikasi tetap sama dan tidak ada perubahan. 58,5\% orang tua menyatakan bahwa komunikasi mereka dengan anak tidak menjadi jarang setelah adanya game online, dan 41,5\% menyatakan komunikasi menjadi berubah menjadi jarang akibat game online (gambar 9).

Kecanduan game online menyebabkan anak mengabaikan waktu tidur, hobi dan bahkan bersosialisasi (Rikky dan Jusuf., 2017). Ditambah, saat ini UI (User Interface) dari beberapa game sudah sangat terlihat realistis dimana karakter dapat disesuaikan dengan minat pengguna. Pada penelitian lain juga dijelaskan, sebagai bagian dari intervensi pemainan game dikalangan remaja dan anak-anak, kemampuan berkomunikasi secara langsung sangat diperlukan. Kebanyakan remaja dan anak-anak tidak bisa berkomunikasi dengan baik pada situasi tatap muka (Rikky dan Jusuf, 2017). Jadi, peran orang tua sangat penting untuk melatih komunikasi di antara anak dan orang tua agar tidak berubah karena game online. 


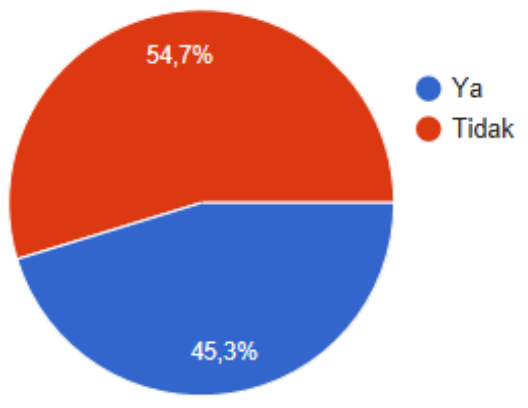

\section{Gambar 10. Perilaku Anak Menjadi Introvert}

Dari 52,8\% anak menghabiskan waktu bermain game lebih banyak dibanding berkumpul dengan keluarga didapatkan fakta $54,7 \%$ menyatakan bahwa hal tersebut tidak membuat anak menjadi seorang introvert dan malas bersosialiasi. Anak memang lebih sering menyendiri saat bermain game dibanding berinteraksi dengan lingkungan sekitarnya. Namun, anak masih mau jika diajak untuk bersosialisasi dengan sekitar. Sisanya $45,3 \%$ mengatakan anak menjadi malas bersosialisasi karena game online (gambar 10). Dari hasil fakta yang ada dapat disimpulkan bahwa anak memang cenderung lebih suka menyendiri ketika bermain game. Pada penelitian yang kami lakukan, bermain game tidak mempengaruhi anak untuk malas bersosialisasi. Dalam beberapa kasus, gamers adalah seorang yang introvert dan memiliki masalah dalam membentuk suatu hubungan sosial di kehidupan nyata dan lebih memilih game sebagai hal penting di hidupnya.

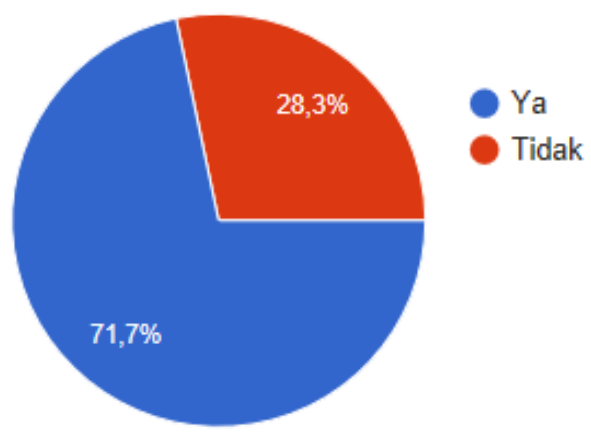

Gambar 11. Perubahan Sikap Anak

$71,7 \%$ menyatakan anak menjadi berubah sikapnya karena bermain game dan 28,3\% mengatakan anak tidak berubah sikapnya karena game online (gambar 11). Pernyataan sebelumnya (gambar 10) menyatakan bahwa anak tidak berubah menjadi introvert karena game, namun pada gambar 11 didapatkan fakta bahwa anak bukan menjadi introvert, melainkan anak berubah sikapnya dari yang awalnya penurut menjadi susah untuk menuruti perintah atau apa yang dikatakan orang tua. Pernyataan-pernyataan sebelumnya telah menjelaskan bahwa anak menjadi acuh tak acuh kepada lingkungan sekitar. Ketika anak sudah asyik bermain game, maka anak akan tidak menghiraukan lingkungan sekitarnya karena game membuat konsentrasi anak menjadi sangat fokus. Menurut referensi Ridwan juga terbukti bahwa anak memang menjadi susah untuk disuruh oleh orang tua ketika asik bermain game dan menjadi lupa waktu (Syahran, 2015).

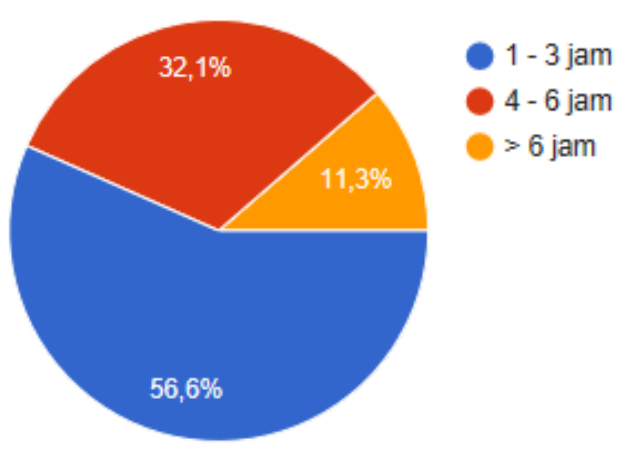

Gambar 11. Lama Bermain Game

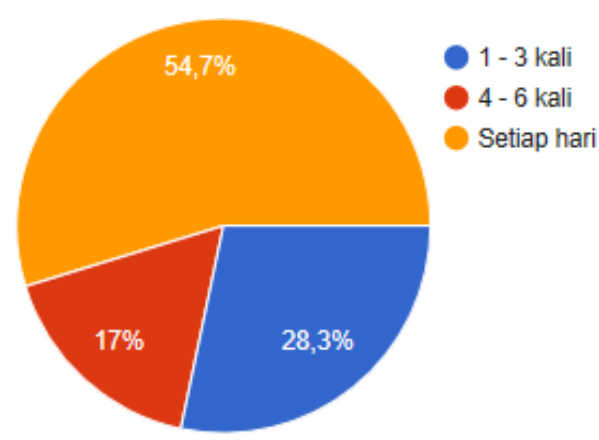

Gambar 12. Jadwal Bermain Game

Gambar 11 menunjukan bahwa rata-rata anak-anak diberi waktu untuk bermain game oleh orang tua sebanyak 1-3 jam yaitu $56.6 \%$, dan pada gambar 12 menunjukan sebanyak $54,7 \%$ orang tua memberikan jadwal anak bermain game yaitu setiap hari.

\section{KESIMPULAN}

Dari penelitian yang dilakukan dapat diambil kesimpulan bahwa di lingkungan Tambakbayan, Yogyakarta game online tidak mempengaruhi komunikasi antara anak dengan orang tua. Hal ini tampak pada hasil dimana didapatkan 58,5\% yang menjawab tidak ada perubahan sebelum dan sesudah anak bermain game. Selain itu orang tua di lingkungan Tambakbayan, Yogyakarta menyikapi kecanduan bermain game online dengan membatasi waktu bermain anak. Perubahan pada anak juga dirasakan oleh orang tua di lingkungan Tambakbayan, Yogyakarta.

\section{SARAN}

Penelitian ini dapat dikembangkan dengan menggunakan metode kualitatif untuk melihat lebih dalam perubahan yang tidak dirasakan maupun 
perubahan seperti apa yang terjadi pada anak-anak yang gemar bermain game online. Selain itu penelitian ini juga dapat diteruskan menggunakan metode kuantitatif untuk mengetahui model/pola yang terjadi dalam masyarakat sehingga hasil yang didapatkan lebih komprehensif baik masalah yang ditemui dan solusi penanggulanganya.

\section{DAFTAR PUSTAKA}

Amarini, I. 2018. "Pencegahan Dampak Negatif Perkembangan Teknologi Informasi Terhadap Pengguna Internet," Kosmik Hukum, 18. doi: 10.30595/kosmikhukum.v18i1.2340.

Aziz, M. S. 2016. "PENGARUH GAME ONLINE TERHADAP PERILAKU KOMUNIKASI ANTAR PERSONAL SISWA KELAS X TSM DI SEKOLAH SMK PGRI 4 KOTA KEDIRI TAHUN PELAJARAN 2015 / 2016 Diajukan untuk Penulisan Skripsi Guna Memenuhi Salah Satu Syarat."

Fajrin, O. R. 2015. "Hubungan Tingkat Penggunaan Teknologi Mobile Gadget dan Eksistensi Permainan Tradisional pada Anak Sekolah Dasar," Jurnal Idea Societa, 2(6), hal. 1-33.

Irianto, A. B. P. 2018. "Automation of Accounting Sysytem in Non Profit Organizations Based On PSAK 45 Standards," in Proceeding of International Conference and Exhibition on Sciences and Technology (ICEST) 2018, hal. 1-8.

Liantoni, F. $d k k$. 2018. "Peran Teknologi Informasi
Untuk Peningkatan Kemampuan Siswa SMA dan SMK Dalam Menghadapi Perkembangan Era Digital," Publikasi Pendidikan, 8. doi: 10.26858/publikan.v8i2.5618.

Mustaffa, C. S. dan Ibrahim, N. Z. M. 2014. "Persepsi dan penggunaan media sosial dari perspektif ibu bapa: Satu Analisis Kualitatif," Malaysian Journal of Communication, 30(Spesial Issue), hal. 43-74.

Nahar, N. $d k k$. 2018. "Impak Negatif Teknologi Moden Dalam Kehidupan Dan Perkembangan KanakKanak Hingga Usia Remaja (Negative Impact of Modern Technology to the Children's Life and their Development)," UMRAN - International Journal of Islamic and Civilizational Studies, 5. doi: 10.11113/umran2018.5n1.181.

Novitasari, W. dan Khotimah, N. 2016. "Dampak Penggunaan Gadget Terhadap Interaksi Sosial Anak Usia 5-6 Tahun," Jurnal PAUD Teratai, 5(3), hal. 182-186.

Paisol Burlian (2016) Patologi Sosial. Jakarta: Bumi Aksara.

Schimmenti, A. $d k k$. 2017. "Personality and Internet Gaming Disorder: a Systematic Review of Recent Literature," Current Addiction Reports. doi: 10.1007/s40429-017-0159-6.

Syahran, R. 2015. "Ketergantungan Game Online dan Penanganannya," Jurnal Psikologi \& Konseling, 1(1), hal. 84-92. 